\title{
MODEL PENGEMBANGAN USAHA PERIKANAN TANGKAP PROSPEKTIF DI WILAYAH PERAIRAN ACEH
}

\author{
Development Model of Prospective Capture Fishing Business in Aceh Waters \\ Oleh: \\ Mustaruddin $^{1}$ dan Julia Eka Astarini ${ }^{1}$ \\ ${ }^{1}$ Departemen Pemanfaatan Sumberdaya Perikanan, FPIK IPB \\ Korespondensi:mus_m03@yahoo.com
}

\begin{abstract}
ABSTRAK
Sektor kelautan dan perikanan dapat menjadi penggerak utama pembangunan di seluruh Indonesia, termasuk di Provinsi Aceh. Hal ini dapat dilakukan dengan mendorong pengembangan usaha perikanan tangkap prospektif yang menopang keberlanjutan usaha dan sumberdaya ikan di masa datang. Penelitian ini bertujuan menentukan jenis usaha perikanan tangkap yang prospektif dan menyusun model pengembangannya di perairan Aceh. Penelitin menggunakan metode analisis prospek investasi dan pemodelan numerik kalkulatif. Usaha jaring insang hanyut (JIH), pancing tonda, jaring insang tetap (JIT), bubu, bagan perahu, dan trammel net propspektif untuk dikembangkan di perairan Aceh, karena mempunyai nilai NPV, IRR, ROI, dan B/C ratio di atas standar, sedangkan perangkap lainnya tidak prospektif. Bila potensi sumberdaya ikan yang belum termanfaatkan di peraran Aceh dikelola $100 \%$ (model III), maka usaha jaring insang hanyut (JIH), pancing tonda, jaring insang tetap (JIT), bubu, bagan perahu, dan trammel net masing-masing dapat ditambah 27 unit, 7 unit, 34 unit, 933 unit, 18 unit, dan 73 unit. Sedangkan jika dikelola $30 \%$ (model I) dan 60 \% (model II), maka keenam usaha perikanan tangkap tersebut masing-masing dapat ditambah 8 unit dan 16 unit, 2 unit dan 4 unit, 10 unit dan 21 unit, 280 unit dan 560 unit, 5 unit dan 11 unit , serta 22 unit dan 44 unit.
\end{abstract}

Kata kunci: model numerik kalkulatif, perairan Aceh, prospek investasi, dan usaha perikanan tangkap

\section{ABSTRACT}

The marine and fisheries sector can be the prime mover of development throughout Indonesia, including in Aceh Province. This can be done by encouraging the development of prospective capture fisheries businesses that guarantee the sustainability of business and fish resources in the future. This study aims to determine the type of prospective capture fisheries business and formulate their development model in Aceh waters. The reseach used the analysis method of investment prospects and calculative numerical modeling. Drift gillnets, trollings, fixed gillnets, fish traps, boat lift nets, and trammel nets were prospective to developed in Aceh waters, because they had NPV, IRR, ROI, and B $\triangle C$ ratio values that according to the standard, while other pitfalls was not prospective. If the potential of untapped fish resources in Aceh was managed 100\% (model III), then the business of drift gillnets, trollings, fixed gillnets, fish traps, boat lift nets, and trammel nets could be added each 27 units, 7 units, 34 units, 933 units, 18 units, and 73 units. Whereas if managed by 30\% (model I) and 60\% (model II), the six capture fisheries businesses could be added each 8 units and 16 units, 2 units and 4 units, 10 units and 21 units, 280 units and 560 units, 5 units and 11 units, 22 units and 44 units.

Key words. calculative numerical model, Aceh waters, investment prospects, and capture fisheries business 


\section{PENDAHULUAN}

Sektor kelautan dan perikanan dapat menjadi penggerak utama (prime mover) pembangunan di seluruh Indonesia, termasuk di Provinsi Aceh. Hal ini karena sektor ini memiliki keunggulan komparatif dibanding sektor lainnya berupa ketersediaan sumberdaya alam yang melimpah, berdaya saing, bernilai ekonomis tinggi, dan dapat dipulihkan kembali sepanjang dikelola secara tepat. Sumberdaya alam yang melimpah yang paling terkenal pada sektor ini adalah sumberdaya ikan laut. Potensi sumberdaya ikan tersebut harus dikelola dengan biak sehingga dapat mewujudkan tujuan pembangunan nasional di bidang kelautan dan perikanan, diantaranya (1) meningkatkan taraf hidup nelayan terutama yang berskala kecil, (2) meningkatkan ketersediaan dan konsumsi sumber protein ikan, (3) mengoptimalkan pemanfaatan sumberdaya ikan dan, dan (4) menjamin kelestarian sumberdaya ikan untuk pemanfaatan di masa mendatang. Tujuan pembangunan tersebut hanya dapat dicapai bila potensi sumberdaya ikan yang ada di wilayah pengelolaan perikanan (WPP) dimanfatkan dengan menggunakan alat/usaha perikanan tangkap yang bertanggung jawab sesuai dengan code of conduct for responsible fisheries (CCFR) yang telah ditetapkan oleh FAO (1995).

Wilayah Provinsi Aceh berbatasan dengan WPP 571 dan WPP 572, serta ada 23 kabupaten/kota yang mempunyai akses langsung kepada kedua WPP tersebut. Dengan kondisi wilayah ini, Provinsi Aceh berpeluang memaksimalkan pencapaian tujuan pembangunan nasional tersebut. Hal ini antara lain dengan mendorong pola-pola pengembangan usaha perikanan tangkap yang lebih memberi kesejahteraan, lebih menjamin kelestarian sumberdaya ikan, serta berpeluang dikembangkan dalam skala investasi baik oleh investor lokal maupun luar. Pengembangan investasi membuka peluang peningkatan produksi ikan, sehingga tujuan pembangunan nasional terkait ketersediaan sumber protein asal ikan dapat lebih terjamin dan pemanfaatan sumberdaya juga lebih optimal. Untuk ini, maka usaha perikanan tangkap yang ditawarkan kepada investor haruslah yang prospeknya baik yang dapat menopang keberlanjutan usaha dan sumberdaya ikan dimasa datang.

Dalam konteks kelestarian sumberdaya ikan seperti tujuan keempat dari pembangunan nasional di bidang kelautan dan perikanan, maka pengembangan investasi usaha perikanan tangkap prospektif harus memperhatikan potensi lestasi sumberdaya ikan di wilayah pengelolaan perikanan. Dan untuk provinsi Aceh, potensi lestari sumberdaya ikan di WPP 571 dan WPP 572 dalam Kepmen No. 45/Men/2011 (KKP, 2011) dapat menjadi acuan terutama bila pengembangan usaha perikanan tangkap dimaksudkan untuk mengoptimalkan pemanfaataan yang ada sehingga sesuai JTB (80\% dari potesi lestari). Namun demikian, pengembangan usaha perikanan tangkap demikian tidaklah mudah karena dipengaruhi oleh banyak faktor, sementara pemanfaatan bertujuan mengoptimalkan. Hal ini dapat dilakukan dengan pendekatan pemodelan, dimana faktor-faktor yang berpengaruh dipertimbangkan dan diakomodir dalam penyusunan model. Penelitian ini bertujuan (a) menenentukan jenis usaha perikanan tangkap yang prospektif untuk dikembangkan di perairan Aceh, dan (b) menyusun model pengembangan usaha perikanan tangkap prospektif di perairan Aceh.

\section{METODE PENELITIAN}

Penelitian ini dilaksanakan di Provinsi Aceh dengan lokasi pengambilan data lapang di Banda Aceh, Pidie Jaya, dan Meulaboh. Waktu pelaksanaan penelitian adalah September-November 2016 dan Mei-Juli 2017. Data yang dikumpulkan dalam penelitian ini terdiri dari data primer dan data sekunder. Data primer terdiri dari ; (a) data usaha perikanan tangkap mencakup kebutuhan investasi, kebutuhan operasional, pendapatan, dan bagi hasil; dan (b) data pengembangan model mencakup data kelompok jenis ikan yang didaratkan, ukuran kapal, jumlah ikan hasil tangkapan dari usaha perikanan tangkap prospektif, dan musim ikan sasaran. Sedangkan data sekunder terdiri dari data time series produksi ikan, potensi lestari sumberdaya ikan di WPP 571 dan WPP 572, serta sebaran usaha perikanan tangkap di WPP 571 dan WPP 572 yang masuk wilayah administrasi Aceh. 
Data primer dikumpulkan dengan teknik wawancara dan pengamatan lapang. Responden wawancara adalah nelayan pemilik/nakhoda dari usaha perikanan tangkap yang dominan dan intensif digunakan, serta pegawai Dinas Kelautan dan Perikanan. Menurut DKP Provinsi Aceh (2017), usaha perikanan tangkap dominan dan intensif digunakan nelayan adalah usaha jaring insang hanyut (JIH), pancing tonda, jaring insang tetap (JIT), bubu, bagan perahu, trammel net, dan perangkap lainnya. Jumlah responden nelayan pemilik/nakhoda ditetapkan 3 orang untuk setiap jenis usaha perikanan tangkap, sedangkan responden dari Dinas Kelautan dan Perikanan berjumlah 2 orang. Pengamatan lapang dilakukan untuk mengumpulkan data terkait kelompok jenis ikan yang didaratkan dan ukuran kapal. Data sekunder dikumpulkan melalui telaah pustaka terhadap buka statistik perikanan yang tersedia di Dinas kelautan dan Perikanan Aceh, Laporan produksi di PPS Lampulo Aceh, laporan studi kasus, serta hasil penelitian yang tersedia di perguruan tinggi dan lembaga riset.

Jenis usaha perikanan tangkap yang prospektif dikembangkan di perairan Aceh ditentukan menggunakan pendekatan analisis prospek/kelayakan investasi. Menurut Mustaruddin et al (2015), kinerja usaha dari segi investasi selalu menjadi ukuran utama investor dalam menanamkan modalnya pada suatu usaha termasuk usaha perikanan tangkap. Sedangkan menurut Mayes \& Shank (2006), analisis kelayakan investasi memberi informasi konkrit dan tuntas tentang masa depan usaha apakah prospek untuk dikembangkan atau justru menjadi sumber masalah baru di kemudian hari. Dalam penelitian ini, parameter investasi yang dianalisis (Mayes \& Shank 2006, Hanley \& Spash 1993) adalah net present value (NPV), internal rate return (IRR), return of investment (ROI), dan benefit-cost ratio (B/C ratio). Suku bunga yang digunakan dalam analisis adalah suku bunga kredit $12 \%$ (Bank Indonesia 2017).

Selanjutnya pengembangan usaha perikanan tangkap yang dinyatakan prospek menggunakan pendekatan pemodelan numerik kalkulatif. Secara prinsip, pemodelan numerik kalkulatif ditujukan untuk mendapatkan hasil pemodelan yang bersifat lebih pasti (mutlak) dengan mengembangkan beberapa analisis matematis yang relevan (Mustaruddin et al 2012). Field (2013) menambahkan bahwa pemodelan numerik merupakan pendekatan untuk mendapatkan pemecahan masalah yang lebih tegas yang dapat dipertanggungjawabkan secara ilmiah. Dengan pemodelan numerik kalkulatif, diharapkan dapat ditentukan jumlah usaha perikanan tangkap (JU) yang dapat dikembangkan/ditambah dengan memperhatikan potensi lestari sumberdaya ikan (MSY) WPP 571 dan WPP 572, luas perairan Aceh (PA) di WPP 571 dan WPP 572, dan tingkat produksi yang eksisting dicapai (prod).

$$
F(J U)=F(M S Y, P A, \text { prod })
$$

Selanjutnya dengan memasukkan faktor koreksi ukuran kapal (UKi), estimasi jumlah hasil tangkapan $\left(\mathrm{JHT}_{\mathrm{i}}\right)$, dan jenis ikan sasaran $\left(\mathrm{JIS}_{\mathrm{i}}\right)$ per usaha perikanan tangkap dapat ditentukan jumlah pengembangan/penambahan untuk setiap jenis usaha perikanan tangkap prospektif $\left(J \mathrm{~J}_{\mathrm{i}}\right)$.

$$
F\left(J U_{i}\right)=F\left(J U, U K_{i}, J H T_{i}, J I S_{i}\right)
$$

Dimana $\mathrm{i}=1,2,3, \ldots . . \mathrm{n}$ (usaha perikanan tangkap prospektif). Ada tiga skenario yang digunakan dalam pemodelan skema pengembangan usaha perikanan tangkap prospektif tersebut, yaitu:

a. Skenario model I : mengelola $30 \%$ dari potensi sumberdaya ikan (SDI) yang belum termanfaatkan

b. Skenario model II : mengelola $60 \%$ dari potensi sumberdaya ikan (SDI) yang belum termanfaatkan

c. Skenario model III : mengelola $100 \%$ dari potensi sumberdaya ikan (SDI) yang belum termanfaatkan atau dengan kata lain meningkatkan produksi hingga 80 \% JTB. 


\section{HASIL DAN PEMBAHASAN}

\section{Usaha Perikanan Tangkap Prospektif}

Analisis prospek investasi merupakan analisis penting untuk mengetahui jenis usaha perikanan tangkap yang prospektif untuk dikembangkan secara komersial di WPP 571 dan WPP 572 yang masuk wilayah administrasi Aceh. Mustaruddin et al (2015) dan Prabowo et al (2013) menyatakan bhwa hasil analisis prospek investasi menjadi pertimbangan pertama dan utama investor untuk menanamkan modal pada suatu jenis usaha perikanan tangkap. Sedangkan menurut Mayes \& Shank (2006) hasil analisis prospek investasi merupakan gambaran masa depan perkembangan usaha termasuk bargening position terhadap persaingan yang terjadi.

Menurut DKP Provinsi Aceh (2017), ada 27 jenis usaha perikanan tangkap yang dijalankan oleh nelayan di Aceh, namun yang populasinya dominan dan intensif digunakan hanya enam jenis, yaitu usaha jaring insang hanyut (JIH), pancing tonda, jaring insang tetap (JIT), bubu, bagan perahu, trammel $n e t$, dan perangkap lainnya. Keenam usaha perikanan tangkap tersebut selanjutnya dianalisis pada bagian ini untuk mengetahui sejauhmana prospeknya dalam mendukung pengembangan perikanan Aceh. Usaha perikanan tangkap tersebut diharapkan dapat diandalkan untuk memanfaatkan potensi sumberdaya ikan (SDI) di perairan Aceh menurut Kepmen No. 45/Men/2011, yaitu potensi ikan pelagis besar, ikan pelagis kecil, ikan demersal, serta udang dan biota laut non ikan. Tabel 1. menyajikan hasil analisis net present value (NPV) keenam usaha perikanan tangkap tersebut

Tabel 1 Nilai net present value (NPV) usaha perikanan tangkap

\begin{tabular}{lcrc}
\hline \multicolumn{1}{c}{ Usaha perikanan tangkap } & Standar & \multicolumn{1}{c}{ NPV } & Keterangan \\
\hline Jaring Insang Hanyut & $>0$ & $1.408 .917 .245,05$ & Layak \\
Pancing Tonda & & $405.923 .154,46$ & Layak \\
Jaring Insang Tetap & & $464.877 .137,87$ & Layak \\
Bubu & & $87.990 .250,42$ & Layak \\
Bagan Perahu & & $1.549 .140 .943,33$ & Layak \\
Trammel net & & $997.171 .396,75$ & Layak \\
Perangkap Lainnya & & $2.953 .285,48$ & Layak \\
\hline
\end{tabular}

Berdasarkan Tabel 1, bagan perahu dan jaring insang hanyut mempunyai nilai NPV paling tinggi yaitu masing-masing Rp 1.549.140.943,33 dan Rp 1.408.917.245,05. Nilai NPV tersebut merupakan gambaran keuntungan bersih bagan perahu dan jaring insang hanyut selama masa operasinya jika diukur dari nilai sekarang yaitu setelah mengakomodir keberadaan suku bunga kredit sekitar $12 \%$. Sedangkan masa operasi (umur teknis) usaha perikanan tangkap untuk digunakan secara normal di Aceh rata-rata 8 tahun. Umur teknis tersebut diukur dari ketahanan barang investasi terbesar (kapal) untuk digunakan secara normal (Mustaruddin et al 2015, Thomas et al 2003) di WPP 571 dan WPP 572 wilayah perairan Aceh.

Pancing tonda, jaring insang tetap, bubu, trammel net juga mempunyai keuntungan bersih yang baik berdasarkan nilai sekarang, karena penerimaannya juga baik sepanjang tahun dan dapat menutupi semua pembiayaan $(\mathrm{NPV}>0)$. Perangkap lainnya mempunyai nilai NPV paling rendah $(2,82 \%)$, diduga karena pola operasinya yang belum stabil. DKP Provinsi Aceh (2017) menyatakan bahwa perangkat lainnya hanya dioperasikan pada saat ombak tenang dan di lokasi-lokasi tertentu yang dangkal. Tabel 2 menyajikan nilai IRR jaring insang hanyut (JIH), pancing tonda, jaring insang tetap (JIT), bubu, bagan perahu, trammel net, dan perangkap lainnya. 
Tabel 2 Nilai internal rate return (IRR) usaha perikanan tangkap

\begin{tabular}{lccl}
\hline \multicolumn{1}{c}{ Usaha perikanan tangkap } & Standar & IRR & Keterangan \\
\hline Jaring Insang Hanyut & $>12 \%$ & $52,54 \%$ & Layak \\
Pancing Tonda & & $55,38 \%$ & Layak \\
Jaring Insang Tetap & & $23,65 \%$ & Layak \\
Bubu & & $25,35 \%$ & Layak \\
Bagan Perahu & $72,40 \%$ & Layak \\
Trammel net & $103,37 \%$ & Layak \\
Perangkap Lainnya & $2,82 \%$ & Tidak layak \\
\hline
\end{tabular}

Berdasarkan Tabel 2, trammel net merupakan usaha perikanan tangkap dengan nilai IRR tertinggi, yaitu 103,37\%. Jaring insang hanyut (JIH), pancing tonda, jaring insang tetap, bubu, dan bagan perahu juga mempunyai IRR yang bagus, yaitu masing-masing 52,54\%, 55,38\%, 23,65\%, 25,35\%, dan 72,40\%. Nilai IRR tersebut menunjukkan bahwa berinvestasi pada keenam usaha perikanan tangkap sangat layak untuk dilakukan meskipun uang yang digunakan berasal dari pinjaman bank. Hal ini karena rasio keuntungan yang diperoleh dapat dengan mudah menutupi bunga pinjaman kredit (12 \% per tahun). Perangkap lainnya tidak layak dikembangkan dari segi IRR. Menurut Prabowo et al (2013), usaha perikanan tangkap akan prospektif pengembangannya, jika rasio keuntungannya dapat menutupi semua pos pembiayaan baik yang berasal dari modal individu maupun pinjaman bank. Tabel 3 menyajikan hasil analisis return of investment (ROI) usaha perikanan tangkap di perairan Aceh (di WPP 571 dan WPP 572).

Tabel 3 Nilai return of investment (ROI)

\begin{tabular}{lccc}
\hline \multicolumn{1}{c}{ Usaha perikanan tangkap } & Standar & ROI & Keterangan \\
\hline Jaring Insang Hanyut & $>1$ & 11,86 & Layak \\
Pancing Tonda & & 18,69 & Layak \\
Jaring Insang Tetap & & 8,99 & Layak \\
Bubu & & 13,67 & Layak \\
Bagan Perahu & & 13,07 & Layak \\
Trammel net & & 27,28 & Layak \\
Perangkap Lainnya & & 26,18 & Layak \\
\hline
\end{tabular}

Keenam usaha perikanan tangkap mempunyai tingkat pengembalian investasi yang baik (ROI >1) (Tabel 3). Usaha trammel net mempunyai nilai ROI paling tinggi, yaitu 27,28. Pengembalian investasi yang tinggi ini diduga karena rasio keuntungan usaha trammel net yang tinggi (nilai NPV = Rp 997.171.396,75), sementara biaya investasinya jauh lebih murah ( $R p$ 190.350.000,00) jika dibandingkan jaring insang hanyut dan jaring insang tetap. Menurut Minarro et al (2016) dan Prabowo et al (2013) tingkat pengembalian investasi yang baik sangat dibutuhkan investor/perusahaan yang sedang berkembang. Hal ini karena, uang investasi dengan cepat dapat dimanfaatkan lagi untuk perlusan usaha. Namun demikian, pengembangan usaha juga harus memperhatikan perimbangan penerimaan dengan pembiayaan. Hal ini penting supaya pembiayaan tidak menjadi beban hutang di masa depan, yang menghambat usaha perikanan tangkap berkembang. Hasil analisis benefit-cost ratio (B/C Ratio) pada Tabel 4 menunjukkan bahwa hanya perangkap lainnya yang pembiayaannya membebani usaha. Pembiayaan usaha perikanan tangkap tersebut sama dengan penerimaannya (B/C ratio $=1,00$ ). Bila penerimaan dialokasikan sebagian untuk bagi hasil, maka diyakini kebutuhan biaya operasional waktu berikutnya berkurang dan untuk mencukupi terpaksa berhutang dan ini bisa terus menerus dilakukan. 
Tabel 4 Nilai benefit-cost ratio(B/C Ratio)

\begin{tabular}{lccc}
\hline \multicolumn{1}{c}{ Usaha perikanan tangkap } & Standar & B/C Ratio & Keterangan \\
\hline Jaring Insang Hanyut & $>1$ & 1,26 & Layak \\
Pancing Tonda & & 1,17 & Layak \\
Jaring Insang Tetap & & 1,13 & Layak \\
Bubu & & 1,09 & Layak \\
Bagan Perahu & & 1,38 & Layak \\
Trammel net & & 1,24 & Layak \\
Perangkap Lainnya & 1,00 & Tidak layak \\
\hline
\end{tabular}

Bila melihat secara keseluruhan dari hasil analisis prospek investasi (NPV, IRR, ROI, dan B/C Ratio), maka jaring insang hanyut (JIH), pancing tonda, jaring insang tetap (JIT), bagan perahu, bubu, dan trammel net prospektif untuk dikembangkan di WPP 571 dan WPP 572 yang masuk wilayah perairan Aceh. Sedangkan perangkat lainnya dinyatakan tidak prospektif. Menurut Field (2013) dan Hanley \& Spash (1993), semua parameter harus terpenuhi dengan baik untuk menyatakan suatu usaha layak atau prospektif untuk dikembangkan. Sedangkan menurut Lancker et al(2019) dan Mustaruddin et al (2015), pemenuhan parameter secara sempurna dapat menjaga eksistensi usaha di tengah persiangan bisnis yang semakin berat dewasa ini.

\section{Model Pengembangan Usaha Perikanan Tangkap Prospektif}

Usaha perikanan tangkap yang dikembangkan di WPP 571 dan WPP 572 yang masuk wilayah adminsitrasi Aceh adalah usaha perikanan tangkap memiliki prospek investasi yang baik berdasarkan ulasan sebelumnya. Usaha perikanan tangkap tersebut adalah jaring insang hanyut (JIH), pancing tonda, jaring insang tetap (JIT), bubu, bagan perahu, dan trammel net. Pengembangan keenam usaha perikanan tangkap melalui pendekatan model ini dimaksudkan untuk mendukung peluang peningkatan produksi ikan di di WPP 571 dan WPP 572 yang masuk wilayah Aceh hingga mendekati JTB (80 \% dari potensi lestari/MSY). Menurut KKP (2011) potensi lestari sumberdaya ikan di WPP 571 dan WPP 572 tersebut masing-masing adalah 276.000 ton/tahun dan 565.200 ton/tahun. Sedangkan luas wilayah perairan laut Aceh di WPP 571 mencapai 2833,35 km2 dan di WPP 572 mencapai 12088,90 km² (DKP Provinsi Aceh 2017).

Pada model ini, ukuran kapal yang dikembangkan diskenariokan sama dengan ukuran kapal yang umum digunakan oleh nelayan Aceh di WPP 571 dan WPP 572 (Tabel 5). Hal ini supaya ABK yang sebagian besar berasal dari masyarakat lokal lebih familiar dalam pengoperasikan usaha perikanan tangkap tersebut.

Tabel 5 Jenis usaha perikanan tangkap, ukuran kapal, dan WPP tempat pengembangan

\begin{tabular}{clcl}
\hline No & Usaha Perikanan Tangkap & $\begin{array}{c}\text { Ukuran Kapal } \\
(\mathrm{GT})\end{array}$ & WPP Tempat Pengembangan \\
\hline 1. & Jaring insang hanyut (JIH) & 68 & WPP 571 dan WPP 572 \\
2. & Pancing tonda & 15 & WPP 571 dan WPP 572 \\
3. & Jaring insang tetap (JIT) & 33 & WPP 571 dan WPP 572 \\
4. & Bubu & 5 & WPP 571 dan WPP 572 \\
5. & Bagan perahu & 30 & WPP 572 \\
6. & Trammel net & 25 & WPP 571 dan WPP 572 \\
\hline
\end{tabular}

Bila diperbandingkan untuk setiap jenis usaha perikanan tangkap, maka ukuran kapal yang digunakan cukup variatif mulai dari ukuran 5 GT hingga ukuran 68 GT (Tabel 5), sehingga memberi banyak alternatif bagi investor dalam berinvestasi. Disamping itu, variasi ukuran kapal tersebut juga memberi peluang untuk pemanfaatan potensi sumberdaya ikan di wilayah perairan terdekat hingga sangat jauh (ZEE), sehingga meminimalisir konflik perebutan fishing ground. Upaya memimalisir 
konflik (terutama dengan nelayan kecil) ini juga yang menjadi pertimbangan bagan perahu diarahkan untuk penangkapan ikan di WPP 572 (bukan di WPP 571) karena perairannya lebih luas (Quimby, 2015).

Hasil identifikasi lapang terkait jumlah hasil tangkapan ikan untuk usaha perikanan tangkap dengan ukuran kapal seperti disajikan pada Tabel 5, menunjukkan bahwa jaring insang hanyut (JIH) sekitar 367,0 ton/unit/tahun, pancing tonda sekitar 82,1 ton/unit/tahun, jaring insang tetap (JIT) sekitar 291,5 ton/unit/tahun, bubu sekitar 15,0 ton/unit/tahun, bagan perahu sekitar 110,6 ton/unit/tahun, trammel net sekitar 105,3 ton/unit/tahun (Tabel 6). Estimasi jumlah hasil tangkapan tersebut sudah mempertimbangkan pola operasi yang terjadi saat ini, musim ikan sasaran (6-8 bulan/tahun) untuk setiap usaha perikanan tangkap (Mustaruddin et al 2017, Kusumawati \& Huang HW 2015), dan estimasi pesimistis penangkapan ikan.

Tabel 6 Hasil tangkapan dan kelompok ikan sasaran untuk setiap jenis usaha perikanan tangkap prospektif

\begin{tabular}{clcl}
\hline No & Usaha Perikanan Tangkap & $\begin{array}{c}\text { Estimasi Hasil } \\
\text { Tangkapan } \\
\text { (ton/unit/tahun) }\end{array}$ & \multicolumn{1}{c}{ Ikan Sasaran } \\
\hline 1. & Jaring insang hanyut (JIH) & 367,0 & Pelagis kecil dan pelagis besar \\
2. & Pancing tonda & 82,1 & Pelagis besar \\
3. & Jaring insang tetap (JIT) & 291,5 & Pelagis kecil dan pelagis besar \\
4. & Bubu & 15,0 & Demersal \\
5. & Bagan perahu & 110,6 & Pelagis kecil dan pelagis besar \\
6. & Trammel net & 105,3 & Udang \& biota laut non ikan \\
\hline
\end{tabular}

Namun demikian, jumlah hasil tangkapan ikan pada Tabel 6 bisa meningkat dan juga bisa menurun tergantung fishing ground dan kondisi cuaca yang terjadi pada saat operasi penangkapan ikan dilakukan. Dari kedua kondisi ini, hasil tangkapan ikan yang menurun tentu kurang baik, dan nelayan/investor perikanan harus dapat memutuskan dengan tepat apakah operasi penangkapan ikan dilanjutkan atau dihentikan sementara. Menurut Olina et al (2016) dan Qumby (2015) usaha perikanan tangkap yang dikelola secara modern bisa menurun drastis hasil tangkapan ikannya (estimasi pesimistis) bila terjadi cuaca buruk pada operasi penangkapan ikan yang dilakukannya. Dalam model pengembangan ini, estimasi pesimistis tersebut diasumsikan hasil tangkapan bisa anjlok $50 \%$ dari kondisi optimal.

Dengan memperhatikan estimasi pesimistis hasil tangkapan ikan untuk setiap jenis usaha perikanan tangkap prospektif, potensi lestari SDI di WPP 571 dan WPP 572, luas wilayah perairan laut Aceh di kedua WPP, dan produksi ikan laut Aceh saat ini di kedua WPP, maka dapat disusun model pengembangan usaha perikanan tangkap baru di WPP 571 dan WPP 572 seperti pada Tabel 7. Pengembangan investasi tersebut dibagi dalam tiga skenario model, yaitu mengelola $30 \%$ (model 1), $60 \%$ (model II), dan $100 \%$ (model III) dari potensi sumberdaya ikan (SDI) yang belum termanfaatkan/peluang peningkatan produksi hingga $80 \%$ JTB.

Berdasarkan Tabel 7, jika potensi SDI yang belum termanfaatkan dikelola hanya 30 \% (model I), maka usaha perikanan tangkap prospektif yang dikembangkan/ditambah di WPP 571 adalah 4 unit untuk jaring insang hanyut (JIH), 0 (tidak ada) untuk pancing tonda, 5 unit untuk jaring insang tetap (JIT), 79 unit untuk bubu, dan 5 unit untuk trammel net. Bila potensi SDI yang belum termanfaatkan tersebut dikelola $60 \%$ (model II), maka usaha perikanan tangkap prospektif yang ditambah meningkat sekitar 2 kali dari model I. Sedangkan jika potensi SDI yang belum termanfaatkan dikelola $100 \%$ (tepat sesuai JTB), maka jumlah jaring insang hanyut (JIH), pancing tonda, jaring insang tetap (JIT), bubu, dan trammel net ang ditambah di WPP 571 adalah masing-masing 13 unit, 0 unit, 17 unit, 263 unit, dan 15 unit. Ukuran usaha perikanan tangkap tersebut mengacu kepada Tabel 5. Pancing tonda tidak ditambah di WPP 571 karena yang ada dianggap cukup. Disamping itu perannya juga bisa diganti oleh 
usaha perikanan tangkap lain yang hasil tangkapannya lebih beragam seperti jaring insang hanyut $(\mathrm{JIH})$ dan jaring insang tetap (JIT). Menurut Setiyawan et al (2016), secara umum pancing (termasuk pancing tonda) lebih diperuntukkan untuk penangkapan ikan pelagis besar, seperti ikan cakalang, tenggiri, dan cakalang. Sedangkan menurut Zydelis et al (2013) dan Thomas et al (2003), gillnet/jaring insang umumnya banyak dipilih karena ikan targetnya tidak terlalu spesifik dan hasil tangkapannya juga banyak.

Tabel 7 Skenario model pengembangan usaha perikanan tangkap prospektif yang baru

\begin{tabular}{|c|c|c|c|c|}
\hline \multirow[b]{2}{*}{ No } & \multirow[b]{2}{*}{ Usaha Perikanan Tangkap } & \multicolumn{3}{|c|}{ Pengembangan Usaha Perikanan Tangkap (unit) } \\
\hline & & $\begin{array}{c}\text { Model I } \\
(30 \% \text { PBT) }\end{array}$ & $\begin{array}{c}\text { Model II } \\
(60 \% \text { PBT) }\end{array}$ & $\begin{array}{c}\text { Model III } \\
(100 \% \text { PBT })\end{array}$ \\
\hline A. & WPP 571 & & & \\
\hline 1. & Jaring insang hanyut $(\mathrm{JIH})$ & 4 & 8 & 13 \\
\hline 2. & Pancing tonda & 0 & 0 & 0 \\
\hline 3. & Jaring insang tetap (JIT) & 5 & 10 & 17 \\
\hline 4. & Bubu & 79 & 158 & 263 \\
\hline 5. & Trammel net & 5 & 9 & 15 \\
\hline B. & WPP 572 & & & \\
\hline 1. & Jaring insang hanyut $(\mathrm{JIH})$ & 4 & 8 & 14 \\
\hline 2. & Pancing tonda & 2 & 4 & 7 \\
\hline 3. & Jaring insang tetap (JIT) & 5 & 10 & 17 \\
\hline 4. & Bubu & 201 & 402 & 670 \\
\hline 5. & Bagan perahu & 5 & 11 & 18 \\
\hline 6. & Trammel net & 17 & 34 & 57 \\
\hline C. & Gabungan (2 WPP) & & & \\
\hline 1. & Jaring insang hanyut $(\mathrm{JIH})$ & 8 & 16 & 27 \\
\hline 2. & Pancing tonda & 2 & 4 & 7 \\
\hline 3. & Jaring insang tetap (JIT) & 10 & 21 & 34 \\
\hline 4. & Bubu & 280 & 560 & 933 \\
\hline 4. & Bagan perahu & 5 & 11 & 18 \\
\hline 5. & Trammel net & 22 & 44 & 73 \\
\hline
\end{tabular}

Keterangan : $P B T=$ potensi yang belum termanfaatkan.

Untuk WPP 572, jika potensi SDI yang belum termanfaatkan dikelola $30 \%$ (model I), maka jaring insang hanyut (JIH) dapat ditambah 4 unit, pancing tonda 2 unit, jaring insang tetap (JIT) 5 unit, bubu 201 unit, bagan perahu 5 unit, dan trammel net 17 unit. Bila potensi SDI yang belum termanfaatkan tersebut dikelola $100 \%$ (model III), maka usaha perikanan tangkap prospektif yang perlu dikembangkan/ditambah adalah 14 unit untuk jaring insang hanyut $(\mathrm{JIH}), 7$ unit untuk pancing tonda, 17 unit untuk jaring insang tetap (JIT), 670 unit untuk bubu, 18 unit untuk bagan perahu, dan 57 unit untuk trammel net. Bila dibandingkan dengan WPP 571, secara umum usaha perikanan tangkap yang ditambah di WPP 572 lebih banyak. Hal ini wilayah perairan Aceh di WPP 572 lebih luas dibandingkan dengan di WPP 571. Menurut DKP Provinsi Aceh (2017), luas wilayah perairan laut Aceh di WPP 572 mencapai 12088,90 km², sedangkan di WPP 571 hanya 2833,35 km². Di samping itu, jumlah usaha perikanan tangkap yang beroperasi di WPP 571 relatif banyak dan beragam (Mustaruddin et al 2017, Kusumawati \& Huang 2015), sehingga peluang pengembangan usaha perikanan tangkap baru lebih sedikit.

Untuk keseluruhan wilayah perairan Aceh dan bila potensi SDI yang belum termanfaatkan dikelola $100 \%$ (tepat sesuai JTB), maka usaha perikanan tangkap prospektif yang dapat ditambah adalah 
27 unit untuk jaring insang hanyut (JIH), 7 unit untuk pancing tonda, 34 unit untuk jaring insang tetap (JIT), 933 unit untuk bubu, 18 unit untuk bagan perahu, dan 73 unit untuk trammel net. Secara umum, penambahan bubu lebih banyak, karena skala pengusahaanya kecil (8 bubu per unit usaha) dan juga satu-satunya yang diperuntukkan bagi ikan demersal dari enam usaha perikanan tangkap prospektif. Menurut Belton et al (2019) dan Quimby (2015), bubu dapat diandalkan untuk perairan-perairan yang masih alami dan banyak ikan demersalnya. Perairan Aceh termasuk perairan yang relatif alami, dan belum banyak aktivitas destruktif di perairannya pantainya, misal bila dibandingkan dengan perairan Jawa dan perairan Bangka-Belitung.

\section{KESIMPULAN DAN SARAN}

\section{Kesimpulan}

Usaha jaring insang hanyut (JIH), pancing tonda, jaring insang tetap (JIT), bubu, bagan perahu, dan trammel net mempunyai nilai NPV > 0, IRR > $12 \%$ (suku bunga kredit), ROI > 1, dan B/C ratio > 1, sehingga prospektif untuk dikembangkan di perairan Aceh. Perangkap lainnya tidak prospektif dikembangkan karena mempunyai IRR dan B/C ratio yang rendah, yaitu masing-masing 2,82 \% dan 1,00. Bila potensi SDI yang belum termanfaatkan di perairan Aceh dikelola $100 \%$ (model III), maka usaha perikanan tangkap prospektif yang dikembangkan/ditambah perairan Aceh adalah 27 unit untuk jaring insang hanyut (JIH), 7 unit untuk pancing tonda, 34 unit untuk jaring insang tetap (JIT), 933 unit untuk bubu, 18 unit untuk bagan perahu, dan 73 unit untuk trammel net. Sedangkan jika potensi tersebut dikelola $30 \%$ (model I) dan 60 \% (model II), maka usaha jaring insang hanyut (JIH), pancing tonda, jaring insang tetap (JIT), bubu, bagan perahu, dan trammel net yang dapat ditambah adalah berturut-turut 8 unit dan 16 unit, 2 unit dan 4 unit, 10 unit dan 21 unit, 280 unit dan 560 unit, 5 unit dan 11 unit, serta 22 unit dan 44 unit.

\section{Saran}

Pengembangan usaha perikanan tangkap prospektif (jaring insang hanyut, pancing tonda, jaring insang tetap, bubu, bagan perahu, dan trammel net) sebaiknya dilakukan secara bertahap mengacu tiga skenario model yang ditawarkan dan dengan memperhatikan trend investasi yang berkembang.

\section{DAFTAR PUSTAKA}

Bank Indonesia. 2017. Pergerakan Suku Bunga Kredit dan Pinjaman. Jakarta (ID): Bank Indonesia.

Belton B, Marschke M, Vandergeest P. 2019. Fisheries development, labour and working conditions on Myanmar's marine resource frontier. Journal of Rural Studies. 69(1): 204-213.

Dinas Kelautan dan Perikanan (DKP) Provinsi Aceh. 2017. Statistik Perikanan Tangkap Tahun 2016. Bandar Aceh (ID): DKP Provinsi Aceh.

Field A. 2013. Discovering statistics using IBM SPSS statistics. $4^{\text {th }}$ Edition. London (UK): SAGE Publications, 960p.

[FAO] Food and Agriculture Organization. Code Of Conduct For Responsible Fisheries (CCRF). Rome : FAO, 1995, pp. 46.

Hanley ND, Spash C. 1993. Cost-Benefic Analysis and the Environment. Edward Elgar. Cheltenham

[KKP] Kementerian Kelautan dan Perikanan. 2011. Keputusan Menteri Kelautan dan Perikanan Republik Indonesia Nomor Kep. 45/Men/2011 tentang Estimasi Potensi Sumberdaya Ikan di Wilayah Pengelolaan Perikanan Negara Republik Indonesia. 
Kusumawati I, Huang HW. 2015. Key factors for successful management of marine protected areas: A comparison of stakeholders' perception of two MPAs in Weh Island, Sabang, Aceh, Indonesia. Journal of Marine Policy. 51(1): 465-475

Lancker K, Fricke L, Schmidt JO. 2019. Assessing the contribution of artisanal fisheries to food security: A bio-economic modeling approach. Food Police. 87(1):1-11.

Mayes TR, Shank TM. 2006. Financial Analysis with Microsoft Excel 4th Edition. South-Western College Pub, Nashville, USA.

Minarro S, Forero GN, Reuter H, van Putten IE. 2016. The role of patron-client relations on the fishing behaviour of artisanal fishermen in the Spermonde Archipelago (Indonesia). Journal of Marine Policy. 69(1): 73-83.

Mustaruddin, Baskoro MS, Kandi O, Nasruddin. 2017. Environmental and Technical Approach In the Selection of Fishing Gear Featured in WPP 571 Aceh. IJSBAR. 31(3): 44-53.

Mustaruddin, Baskoro MS, Purwanto B. 2015. Pengembangan investasi usaha perikanan tangkap unggulan di Bau-bau, Sulawesi Tenggara. Prosiding Seminar Nasional Perikanan Tangkap VI, 22 Oktober 2015. Hal 193-207.

Mustaruddin, Nurani TW, Wisudo SH, Wiyono ES, Haluan J. 2012. Pendekatan Kuantitatif untuk Pengembangan Operasi Industri Perikanan. Bandung (ID): CV. Lubuk Agung. 226 hal

Olina M, Tiainena J, Kurkilahtib M, Raskc M, Lehtonena H. 2016. An evaluation of gillnet CPUE as an index of perch density in small forest lakes. Fisheries Research. 173(1): 20-25.

Prabowo, Wiyono ES, Haluan J, Iskandar BH. 2013. Kinerja pembiayaan perikanan skala kecil di Kota Tegal, Provinsi Jawa Tengah. Marine Fisheries. 4(1): 1-9.

Setiyawan A, Sadiyah L, dan Samsuddin S. 2016. Faktor-faktor penting yang mempengaruhi CPUE (catch per unit effort) perikanan huhate berbasis di Bitung. Jurnal Penelitian Perikanan Indonesia, 22(1): 43-50.

Thomas SN, Edwin L, and George VC. 2003. Catching efficiency of gill nets and trammel nets for penaeid prawns. Journal of Fisheries Research. 60(1): 141-150, 2003.

Quimby B. 2015. Emerging customs: Small-scale fishing practices in Aceh, Indonesia. Journal of Applied Geography. 59 (1): 125-130.

Zydelis R, Small C, and French G. 2013. The incidental catch of seabirds in gillnet fisheries: A global review. Journal of Biological Conservation, 162(1): 76-88. 